\title{
Promoting Teaching Excellence of Universities in Taiwan: Policy Analysis with a Special Reference to Educational Equality
}

\author{
Cheng-Cheng Yang ${ }^{1} \&$ Yueh-Chun Huang ${ }^{1}$ \\ ${ }^{1}$ Graduate Institute of Educational Administration and Policy Development, National Chiayi University, Taiwan \\ Correspondence: Yueh-Chun Huang, Associate Professor, Graduate Institute of Educational Administration and \\ Policy Development, National Chiayi University, Taiwan. Tel: 886-5226-3411. E-mail: \\ ychuang100@mail.ncyu.edu.tw
}

Received: May 10, 2012 Accepted: June 11, 2012 Online Published: August 13, 2012

doi:10.5539/ies.v5n5p129 URL: http://dx.doi.org/10.5539/ies.v5n5p129

\begin{abstract}
As some comparative educators predict, educational policies will move toward similar paths when globalization becomes more powerful. The global higher education expansion in the past decades is one example. The quest of establishing world class universities in the world is another case. The Taiwan government experiences challenges from expansion of universities, the next step is to ensure the "quality" of higher education. In this context, "Program for Promoting Teaching Excellence of Universities, PPTEU" is one of the important policies in Taiwan. This research aims at exploring this policy and its possible effects by analyzing related literatures, policy document, and statistical data collected from the Ministry of Education in Taiwan. This research also highlights the relationship between the newly trend of establishing world-class universities, differentiation of universities, and teaching excellence in Taiwan. Statistical data of PPTEU collected by Ministry of Education in Taiwan was analyzed with a special reference to educational equality. Policy and research implications were discussed in the last section of this research.
\end{abstract}

Keywords: teaching in university, quality assurance in higher education, educational equality, Taiwan

\section{Introduction}

As some comparative educators predict, educational policies will move toward similar paths when globalization becomes more powerful. The expansion of educational opportunities is one of these trends. Indeed, in the last three decades, higher education expansion in Taiwan has provided profound educational opportunities for high school graduates in Taiwan. The next step for the Taiwan government is to ensure the "quality" of various higher education institutions in Taiwan. In this context, "Program for Promoting Teaching Excellence of Universities, PPTEU" is one of the important policies in Taiwan. This research aims at exploring this policy and its possible effects by analyzing related literatures, policy document, and statistical data collected from the Ministry of Education in Taiwan. This research also highlights the relationship between the newly trend of establishing world-class universities, differentiation of universities, and teaching excellence in Taiwan. This research critically examines the effects of this policy from the viewpoint of social justice and educational equality.

This research can be divided into three sections. In the first section, we review related literatures which include theories of teaching excellence, empirical studies of teaching excellence, and international policies of teaching excellence. In the second section of this research, we review the policy documents of PPTEU. We also include the context of higher education changes of Taiwan in the last decade in this section. These changes include the increasing numbers of universities, the desire of pursuing world class universities, and the development of differentiating universities in Taiwan. In the third section, statistical data of PPTEU collected by Ministry of Education in Taiwan was analyzed with a special reference to educational equality. Policy and research implications were discussed in the last section of this research.

\section{Review of the Related Literature}

In the second section of this research, we will review literatures about teaching excellence in the level of higher education. Literature review was divided into three subsections: perspectives of theories, empirical studies, and international policies. 


\subsection{Teaching Excellence of Universities: Perspective of Theories}

"Teaching excellence" in universities is highly associated with wider social and technological changes. The application of new instructional technologies is one of the most significant changes of higher education institutions (HEIs) (Hannan \& Silver, 2000). But, when we think teaching excellence in the level of university, we cannot neglect different theories of college student development (Skelton, 2004).

\subsubsection{Student Involvement Theory}

Student involvement theory is developed by Astin (1999) via a series of college student psychological and behavioral researches (Astin, 1973, 1975, 1977). The definition of student involvement, according to Astin (1999, p.518), is "the amount of physical and psychological energy that the student devotes to the academic experience." The hypothesis of student involvement theory is that the more involvement college students have in academic and social activities on campus, the better collegiate outcome they will possess (Astin, 1999). In terms of the question "how to measure student involvement?" Astin (1999) believes that "student time" is an important indicator of measuring student involvement. Therefore, student involvement variables can include time and effort that students spend on studying, interacting with faculty and others, participating in student activities, and doing on-campus work study (Astin, 1999).

Astin (1999) argues that student involvement should be considered as a longitudinal process. According to the relevant studies, student involvement is proved to be associated with academic achievement and learning outcomes. Thus, student involvement, according to Astin (1999), should be encouraged by higher education institutions (HEIs) to enhance educational effectiveness. Student involvement theory can be seen as a conceptual framework that guides HEIs, administrators, and researchers to think about how to organize college environment, campus facilities, student activities, and instructional methods to facilitate student involvement behaviors (Astin, 1999).

\subsubsection{I-E-O Model}

In order to explore what kind of college student involvement behavior and college environment variable will enhance student's learning outcome within the collegiate environment. Astin (2002) develops a methodology for studying the impact of college environment and the longitudinal change of college student. This methodological framework is called Input-Environment-Outcome (I-E-O) model. Figure 1 offers a conceptual diagram of I-E-O model. This model is developed to trace the change of college students and to discover influential factors of college environment via longitudinal data analysis. In this model, outcome refers to the dependent variable or outcome variable that the researcher is going to measure. For example, when research is conducted to study the impact of an educational program on student's GPA, then GPA is a outcome variable. Input refers to a student's personal characteristics before the educational program that they will participate in, for example, pretest of outcome variable, such as college freshman's GPA (when outcome variable is college junior's GPA). Environment refers to the educational program that students will participate in. This educational program is designed as an educational activity to enhance student's outcome (Astin, 2002).

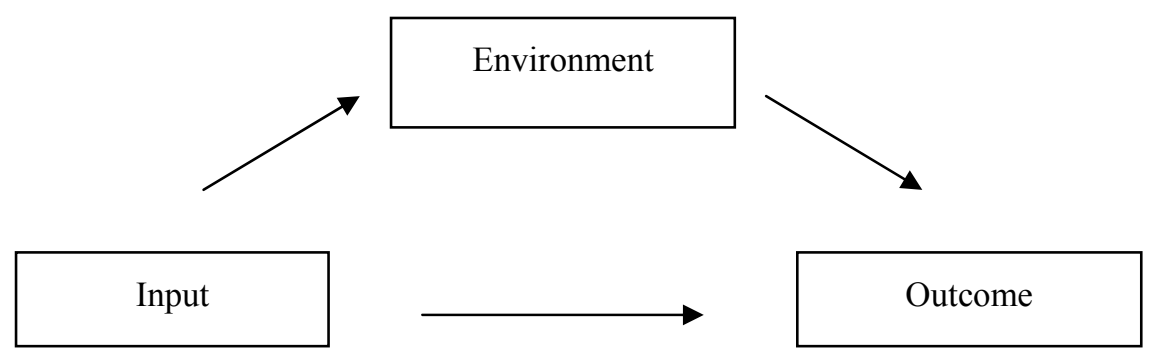

Figure 1. Conceptual Diagram of I-E-O Model

Source: Astin (2002).

\subsection{Teaching Excellence of Universities: Perspective of Empirical Studies}

It is always argued by studies that teaching is undervalued at research-intensive universities (Kreber, 2002). Some articles starts to rethink this issue and one strong argument is to extend the meaning of "scholarship". 
Scholarship should be more than the discovery of new knowledge in the discipline. Scholarship also means to be the integration, application, and transmission of knowledge. And this kind of concept of scholarship is the "scholarship of teaching" (Kreber, 2002).

The idea of "scholarship of teaching" is more than the teaching excellence. It is the idea of a continual learning process of university faculty who can on the one hand develops his teaching expertise and on the other hand publishes related findings in peer-reviewed media (Kreber, 2002).

Cambridge (2000) argues that "the scholarship of teaching is not aimed exclusively at publication. Scholars of teaching and learning are exploring multiple ways of making their work public, including the internet, faculty development activities, and public presentations".

\subsection{Teaching Excellence of Universities: Perspective of International Policies}

\subsubsection{Teaching Award Scheme}

Table 1 is a list of teaching award schemes that are implemented in some countries in the world. The practices of rewarding university teaching, as showed in the table, are varied among different states and governments. Australia focuses on a subject-based reward process, when professors demonstrated their excellence in teaching, then they will be rewarded individually. Australia's reward system could be the most unique in the list, other countries include Canada, the United Kingdom, and the United States, are more focusing on selecting excellent teaching practice among all professors. This analysis shows that Australia could be one of the pioneers that think different subject will have different model of excellent teaching.

Table 1. Comparison of award schemes/programs in different countries

\begin{tabular}{|c|c|c|c|c|}
\hline Name & Country & Nature & Funding Mechanism & Focus and Aim \\
\hline $\begin{array}{l}\text { United States } \\
\text { Professors of the } \\
\text { Year Program }\end{array}$ & $\begin{array}{l}\text { United } \\
\text { States of } \\
\text { America }\end{array}$ & $\begin{array}{l}\text { USD } 5 \mathrm{k} ; 4 \text { awards, } 1 \\
\text { in each of } 4 \\
\text { categories }\end{array}$ & $\begin{array}{l}\text { This is a } \\
\text { general-based award, } \\
\text { select best teaching } \\
\text { individual }\end{array}$ & $\begin{array}{l}\text { Reward and } \\
\text { development } \\
\text { these } \\
\text { individuals' } \\
\text { teaching }\end{array}$ \\
\hline $\begin{array}{l}\text { Canadian 3M } \\
\text { Teaching } \\
\text { Fellowships }\end{array}$ & Canada & $\begin{array}{l}\text { Expense-paid 3-day } \\
\text { retreat }\end{array}$ & $\begin{array}{l}\text { Two categories: } \\
\text { General-based and } \\
\text { subject-based }\end{array}$ & $\begin{array}{l}\text { Reward and } \\
\text { development } \\
\text { these } \\
\text { individuals' } \\
\text { teaching }\end{array}$ \\
\hline $\begin{array}{l}\text { National Teaching } \\
\text { Fellowship } \\
\text { Scheme (NTFS) } \\
\text { (England \& NI) }\end{array}$ & $\begin{array}{l}\text { The United } \\
\text { Kingdom }\end{array}$ & $\begin{array}{l}\text { 50k pound; } 20 \\
\text { individual awards }\end{array}$ & $\begin{array}{l}\text { This is a } \\
\text { general-based award, } \\
\text { select best teaching } \\
\text { individual }\end{array}$ & $\begin{array}{l}\text { Reward and } \\
\text { development } \\
\text { these } \\
\text { individuals' } \\
\text { teaching }\end{array}$ \\
\hline $\begin{array}{l}\text { Australian Awards } \\
\text { for University } \\
\text { Teaching }\end{array}$ & Australia & $\begin{array}{l}\$ 40-100 \mathrm{~K} ; 16 \text { awards } \\
\text { in } 4 \text { categories } \\
\text { (individual, themed, } \\
\text { institutional, overall) }\end{array}$ & $\begin{array}{l}\text { Subject-based. Award } \\
\text { best teaching } \\
\text { individual faculty }\end{array}$ & $\begin{array}{l}\text { Reward and } \\
\text { development } \\
\text { these } \\
\text { individuals' } \\
\text { teaching }\end{array}$ \\
\hline $\begin{array}{l}\text { Promoting } \\
\text { Teaching } \\
\text { Excellence of } \\
\text { Universities } \\
\text { Program }\end{array}$ & Taiwan & $\begin{array}{l}\text { Varied total funding } \\
\text { from the Taiwan } \\
\text { government and } \\
\text { shared by awarded } \\
\text { institutions }\end{array}$ & $\begin{array}{l}\text { Institution-based, the } \\
\text { government will offer } \\
\text { funding to good } \\
\text { teaching practice } \\
\text { universities, then } \\
\text { these institutions will } \\
\text { use this fund to } \\
\text { improve their } \\
\text { teaching }\end{array}$ & $\begin{array}{l}\text { Reward and } \\
\text { develop these } \\
\text { universities' } \\
\text { teaching quality }\end{array}$ \\
\hline
\end{tabular}

Source: Skelton (2004: 453) and Ministry of Education in Taiwan (2012a, 2012b) 


\section{Policy of Promoting Teaching Excellence of Universities: The Case of Taiwan}

\subsection{Theoretical Framework: MMI and EMI}

Classic sociological conflict theories, such as social reproduction theory, purport that education is to serve upper class and its function is to justify the existence of social stratification via the social mechanisms of meritocracy, academic competition, and standardized tests (Bowles \& Gintis, 1976). Cultural reproduction theory, in turn, provides supplemental explanation of how education, society, and cultural difference reproduce social stratification (Bourdieu \& Passeron, 1990). Indeed, empirical studies have provided evidence that students' social class and cultural capital would consistently constrain their college access opportunities (McDonough, 1997; Paulsen, 2001). However, social and cultural reproduction theories have relatively fewer accounts about the role of the state and education planning with educational expansion and educational opportunities. Arum, Gamoran, and Shavit (2007, p.1) write an important statement about educational expansion and opportunity, that is:

"For scholars of social stratification, the key question about educational expansion is whether it reduces inequality by providing more opportunities for persons from disadvantaged strata, or magnifies inequality by expanding opportunities disproportionately for those who are already privileged (Arum, Gamoran, \& Shavit, 2007, p.1)."

To answer this question, there are two sociological theories that try to explain the relationship between educational expansion and inequality of educational opportunities. These two theories are Maximum Maintained Inequality Hypothesis and Effectively Maintained Inequality Hypothesis.

\subsubsection{Maximum Maintained Inequality Hypothesis}

Maximum Maintained Inequality (MMI) hypothesis is a sociological theory that explains the relationship between educational expansion and inequality of educational opportunity. This theory proposes a hypothesis that when educational expansion in a country provides more educational opportunities, the advantaged groups (i.e., high income residents) will still have more educational opportunities than disadvantaged groups (i.e., low income residents). Only when nearly all advantaged origin children's needs of access into that educational level are satisfied, the access rate of disadvantaged origin children will start to increase.

Raftery and Hout (1993) developed the MMI hypothesis based on Mare's (1981) classic work on educational attainment and social stratification. They examined the secondary education expansion in Ireland and generated a hypothesis that in the process of educational expansion in a country, the inequality of opportunity in that education level will decrease only when the enrollment needs of the elite strata are saturated (Note 1). When the education level's (i.e., postsecondary level) enrollment is not universal, the elite social stratum will profit more from educational expansion than the less privileged, and increase their attendance rates faster.

MMI hypothesis, as applied by many scholars, is a valid hypothesis for studying educational expansion, educational opportunity, and social inequality (Arum, Gamoran, \& Shavit, 2007; Hout \& DiPrete, 2006; Raftery \& Hout, 1993). The positive part of MMI hypothesis is that this theory also recognizes the positive effect of educational expansion. That means, even though advantaged social groups have a higher probability to benefit from the growth of educational opportunities, educational expansion can still provide educational opportunities for disadvantaged social groups when most educational needs of advantaged social groups are satisfied.

\subsubsection{Effectively Maintained Inequality Hypothesis}

Though MMI has been recognized by many studies as a valid framework for studying educational inequality (Arum, Gamoran, \& Shavit, 2007; Hout \& DiPrete, 2006; Raftery \& Hout, 1993), it was criticized by recent studies that it ignores the existence of tracking and qualitative differentiation in education (Ayalon \& Shavit, 2004; Lucas, 2001). As Arum, Gamoran, and Shavit (2007) pointed out, student's educational decision making not only includes to continue or to drop out, it also includes school choices. In other words, the MMI hypothesis ignores the qualitative difference between schools in all levels of education (Shavit, Ayalon, Chachashvili-Bolotin, \& Menahem, 2007).

The critiques of MMI hypothesis remind that when we study college access and equity in the context of higher education expansion, we must take the qualitative variation between institutions into consideration (Shavit, Ayalon, Chachashvili-Bolotin, \& Menahem, 2007). Based on the critiques of MMI and new studies of educational expansion and educational transition, Lucas (2001) developed the Effectively Maintained Inequality (EMI) hypothesis, this hypothesis argues that educational inequality may exist via qualitative differentiation in the process of educational expansion. For example, at times of higher education expansion, though students from lower income families would have more college access opportunities than before, students from higher income 
families would have more chances to attend higher rank or first tier universities. The hypothesis of EMI inspired reflective thinking on differentiation in education, scholars started to call for studies to explore educational inequality in the levels of education which has reached quantitative equality (Lucas, 2001; Shavit, Ayalon, Chachashvili-Bolotin, \& Menahem, 2007; Tsai \& Shavit, 2007). Scholars also point out that EMI hypothesis is especially valuable for studying higher education expansion because higher education institutions in many countries are highly diversified (Shavit, Ayalon, Chachashvili-Bolotin, \& Menahem, 2007).

Through the above literature review, a conceptual hypothesis is that the expansion of education and the development of compulsory education can help solve educational inequalities in various levels of education. However, in the level of higher education, because of the different tasks of higher education (to do innovative studies or to teach practical knowledge), differentiation in higher education becomes a practical way to balance the budget and functional diversity among institutions, which has been implemented in many higher education systems in the world. However, as EMI theory reminds us that qualitative differences between institutions could lead to another form of educational inequality and social reproduction, we cannot neglect the importance of examining educational inequality in the context of higher education differentiation.

\subsection{Structural Framework of the Higher Education System in Taiwan}

\subsubsection{Transition System of Higher Education in Taiwan}

In the current Taiwanese education system, there are two transitional tracks: academic track and technical track (Lin \& Chan, 2004; Ministry of Education in Taiwan, 1999). The differentiation of the two pathways begins from the secondary education level; senior high schools in Taiwan are diverted into academic system and vocational system. After senior high schools, when students enter college, they are diverted into two main higher education access tracks: (1) academic universities and colleges, which include research universities, normal universities, teacher colleges, and medical colleges; (2) technical universities and colleges, which include universities and colleges of technological research and innovations. Figure 2 presents the current higher education transition system in Taiwan.

\begin{tabular}{|c|c|c|c|}
\hline $\begin{array}{c}\text { Academic } \\
\text { Universities \& } \\
\text { Colleges (4 YRS.) }\end{array}$ & $\begin{array}{c}\text { Technical } \\
\text { Universities \& } \\
\text { Colleges (4 YRS.) }\end{array}$ & \multicolumn{2}{|c|}{$\begin{array}{c}\text { Technical Univ \& } \\
\text { College (2 YRS.) }\end{array}$} \\
\cline { 2 - 2 } & & $\begin{array}{c}\text { Junior College } \\
\text { (2 YRS.) }\end{array}$ & $\begin{array}{c}\text { Junior } \\
\text { College } \\
\text { (5 YRS.) }\end{array}$ \\
\hline $\begin{array}{c}\text { Senior High Schools } \\
\text { (3YRS.) }\end{array}$ & \multicolumn{2}{|c|}{ Senior Vocational High Schools } \\
(3YRS.)
\end{tabular}

Figure 2. Higher Education Transition System in Taiwan

Source: Ministry of Education in Taiwan (2008).

\subsubsection{World Class University Policy and Differentiation of Higher Education in Taiwan}

Globalization and the transforming knowledge-based economy, as Mok (2003) points out, have caused the restructure of higher education in East Asia. Indeed, the recent pressure from globalization and international higher education rankings has pushed the Taiwanese government to start thinking the global competitiveness of top research universities in Taiwan. Global academic competition among universities was reinforced by international higher education rankings published by the media, magazines, and research institutes.

Back to the year of 1986, there were only 27 academic universities/colleges in Taiwan, and the function of these HEIs was on research and teaching. These HEIs include comprehensive universities, normal universities, teachers colleges, and medical colleges. There were also 77 junior colleges in the system, their function was on teaching and vocational training. These two tiers of HEIs were composed by both public and private 
universities/colleges. Junior college graduates could have the opportunities to transfer into the junior class of the academic universities/colleges.

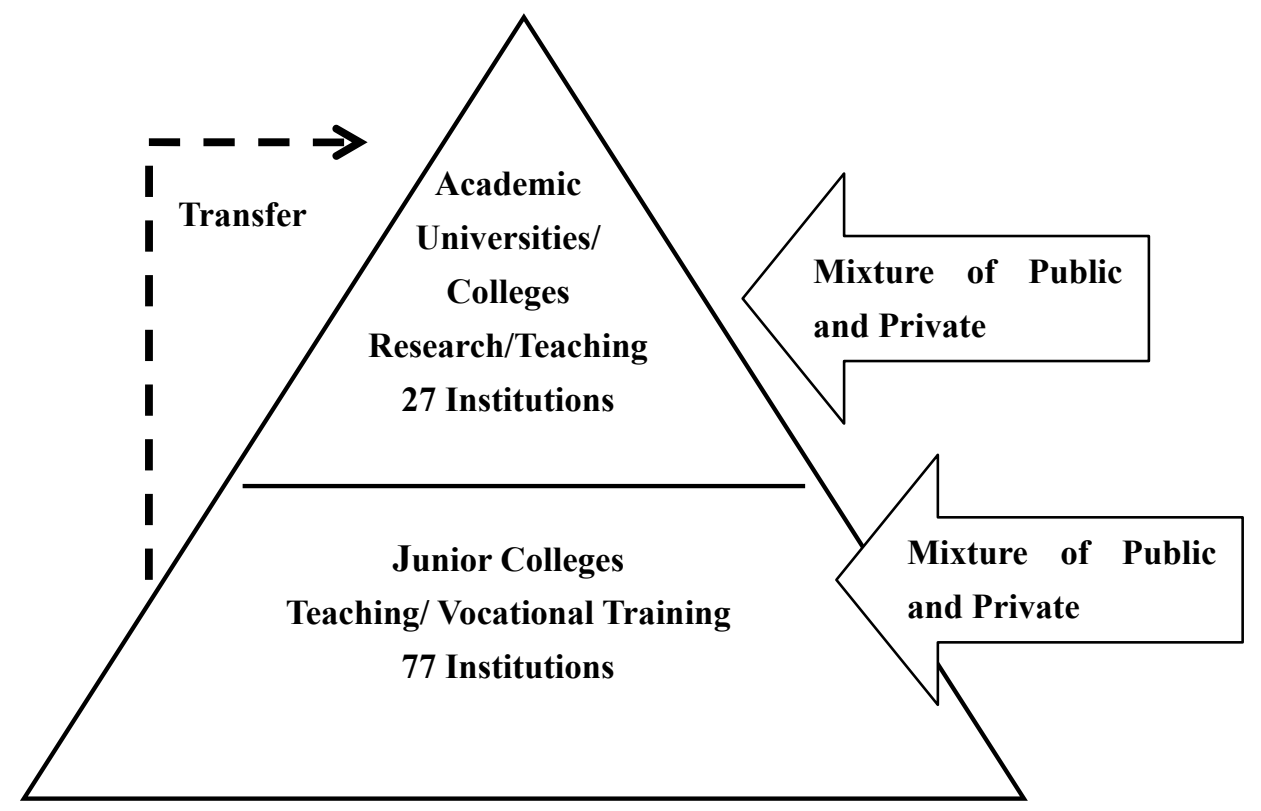

Figure 3. Conceptual Diagram of Higher Education System in Taiwan in 1986

Figure 4 is the conceptual diagram of the higher education system in the year of 2008 . The system has changed a lot comparing with the year of 1986. After 22 years of social and education reform in Taiwan, the total number of HEIs has increased significantly. The implementation of world class university policy in this country has differentiated the system into three types of HEIs. The first type is the world class policy universities which include 11 HEIs and most of them are public universities. The second type is the academic universities/colleges which include 59 HEIs and half of them are public and half of them are private. The third type is the technical universities/colleges which include 77 HEIs and $79 \%$ of them is private HEIs. The main function of WCUP HEIs is research, whereas academic HEIs take more responsibility on research and teaching and technical HEIs are on research, teaching, and vocational training.

Based on the research finding of Ayalon and Shavit (2004) and Tsai and Shavit (2007), the stratification of higher education system could become a possible problem when the quantity of educational opportunities has been satisfied and the quality difference between schools could be widen when some schools could generate more resources from the governments, parents, and students. Taiwan is no exception of this trend. Yang (2010) has analyzed the case of Taiwan by the governmental data and points out that students with higher social economic status would have significant higher opportunities of accessing universities of world class university policy. 


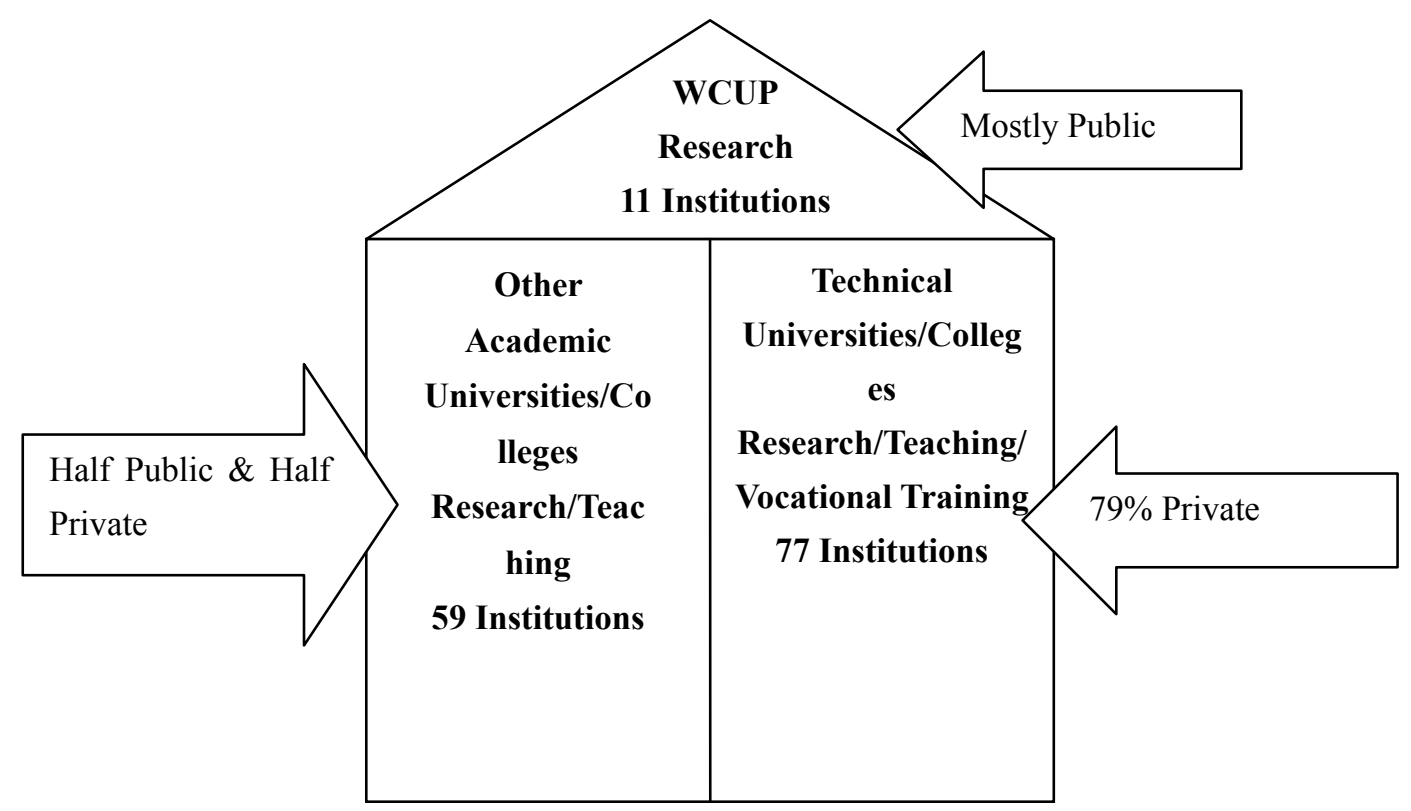

Figure 4. Conceptual Diagram of Higher Education System in Taiwan in 2008

\subsection{Policy Discourse of Promoting Teaching Excellence of Universities in Taiwan}

The context of the Policy of Promoting Teaching Excellence of Universities (PPTEU) comes out of the reflection on the rapid growth of higher education institutions (HEIs) in Taiwan. This policy is out the ideal of balancing the quality of research and teaching of different types of HEIs in Taiwan. The second purpose of this policy is to achieve the goal of reducing educational inequalities within the hierarchy of HEIs in Taiwan. As Ministry of Education in Taiwan (2012a) said in its policy promotion document:

"Because of social change and the needs of higher education opportunities, the number of universities grows rapidly, higher education has changed from traditional elite system to a mass system......however, because of this rapid growth, the quality of college education is questioned and their competiveness is not enough for the future of globalization" (Ministry of Education in Taiwan, 2012a)

"Promoting teaching excellence in the level of higher education has been recognized by many countries in the world. Many governments and nation states all try different ways to develop their higher education and try to enhance faculty's expertise in teaching. However, the current situation of Taiwan is to put too much focus and resources on research, and very little focus on faculty's teaching" (Ministry of Education in Taiwan, 2012a)

"Therefore, starting from the year of 2004, the Ministry of Education in Taiwan implemented the policy of promoting teaching excellence of universities. In the academic year of 2005-2006, the MOE will fund one billion NTD to this policy by competitive reward mechanism. In the year of 2006-2007, the MOE in Taiwan will increase the total fund of this policy to five billion NTD" (Ministry of Education in Taiwan, 2012a)

\subsection{Promoting Teaching Excellence of Universities in Taiwan: Characteristic Comparison among Selected HEIs}

\subsubsection{Longitudinal Change of PPTEU: 2005-2011}

Table 2 , table 3 , table 4 , and table 5 are statistical data that analyzed by our research team. The raw data is released by the Ministry of Education in Taiwan. We tried to analyze these data and divide them into public and private sectors. As table 2 showed, the total number of awarded HEIs increased significant after the first year. And after the year of 2007, the number is stable and is about 30 HEIs in this policy. There is a trend that there are more and more private HEIs win this award in the process of competition mechanism that implemented by the MOE in Taiwan. 
Table 2. Numbers of Awarded HEIs of PPTEU: 2005-2011

\begin{tabular}{|c|c|c|c|c|c|c|c|}
\hline \multicolumn{2}{|l|}{ Academic Year } & $2005-2006$ & $2006-2007$ & $2007-2008$ & $2008-2009$ & $2009-2010$ & $2010-2011$ \\
\hline Awarded HEIs & & 13 & 28 & 30 & 30 & 31 & 31 \\
\hline $\begin{array}{l}\text { Awarded } \\
\text { HEIs }\end{array}$ & Public & 5 & 13 & 14 & 13 & 11 & 11 \\
\hline $\begin{array}{l}\text { Awarded } \\
\text { HEIs }\end{array}$ & Private & & 15 & 16 & 17 & 20 & 20 \\
\hline
\end{tabular}

Source: Ministry of Education in Taiwan (2012b)

Table 3 is the numbers of awarded HEIs and we divide the data into different areas of Taiwan. Generally speaking, the regional difference of Taiwan is, north area and central area is highly urbanized, whereas southern is relatively less urbanized. The eastern area is more ruralized. Thus we can find a trend that though the total number of awarded HEIs does not change significantly. But the Taiwanese government and MOE did try to balance the regional divide via the PPTEU.

Table 3. Numbers of Awarded HEIs: Comparison of Location: 2007-2011

\begin{tabular}{lllll}
\hline Academic Year & $2007-2008$ & $2008-2009$ & $2009-2010$ & $2010-2011$ \\
\hline $\begin{array}{l}\text { Awarded HEIs located in Northern } \\
\text { Area }\end{array}$ & 16 & 17 & 16 & 15 \\
$\begin{array}{l}\text { Awarded HEIs located in Central Area } \\
\text { Awarded HEIs located in Southern }\end{array}$ & 5 & 7 & 5 & 6 \\
$\begin{array}{l}\text { Area } \\
\text { Awarded HEIs located in Eastern Area }\end{array}$ & 1 & 3 & 6 & 5 \\
\hline
\end{tabular}

Source: Ministry of Education in Taiwan (2012b)

Table 4 is the numbers of awarded HEIs and we tried to differentiate the HEIs by their institutional types. As the data showed, the number of comprehensive university grows from 20 to 24 from the year 2007 to the year of 2011, whereas teachers college/normal university becomes less in the total number of HEIs. The number of specialized university also decreased in this phase of time.

Table 4. Numbers of Awarded HEIs: Comparison of Institutional Types: 2007-2011

\begin{tabular}{lllll}
\hline Academic Year & $2007-2008$ & $2008-2009$ & $2009-2010$ & $2010-2011$ \\
\hline Awarded HEIs-Comprehensive & 20 & 20 & 24 & 24 \\
University & & & & 2 \\
Awarded HEIs-Teachers College or & 3 & 3 & 3 & 5 \\
$\begin{array}{l}\text { Normal University } \\
\text { Awarded HEIs-Specialized Univeristy }\end{array}$ & 7 & 7 & 4 & 5
\end{tabular}

Source: Ministry of Education in Taiwan (2012b)

Table 5 is the data of total and average funding of public and private HEIs awarded by this policy. The total funding grows significantly from the year of 2005 to the year of 2011. This reveals the Taiwan government's concern on university's teaching. In terms of the average funding, the trend of average funding for public HEIs is decreasing, whereas the average funding for private HEIs is also decreasing (despite the year of 2009-2010). Our explanation on this change is the Taiwan government tried to provide funding for more HEIs, thus the average funding for both public and private HEIs was decreasing over this period of time. 
Table 5. Total and Average Funding of PPTEU: 2005-2011

\begin{tabular}{lllllll}
\hline Academic Year & $2005-2006$ & $2006-2007$ & $2007-2008$ & $2008-2009$ & $2009-2010$ & $2010-2011$ \\
\hline $\begin{array}{l}\text { Total Funding } \\
\begin{array}{l}\text { Total Funding-Public } \\
\text { HEIs }\end{array}\end{array}$ & 1229 & 1850 & 1678.77 & 1760.71 & 2232 & 1542.02 \\
$\begin{array}{l}\text { Total Funding-Private } \\
\text { HEIs }\end{array}$ & 790 & 1103 & 1080.83 & 1176.12 & 1668 & 1134.11 \\
$\begin{array}{l}\text { Average } \\
\text { Funding-Public HEIs }\end{array}$ & 87.8 & 57.46 & 42.71 & 44.96 & 51.27 & 37.08 \\
$\begin{array}{l}\text { Average } \\
\text { Funding-Private HEIs }\end{array}$ & 98.75 & 73.53 & 67.55 & 69.18 & 83.4 & 56.7 \\
\hline
\end{tabular}

Unit: Million

Source: Ministry of Education in Taiwan (2012b)

\subsubsection{Profile and Statistics of Selected HEIs of PPTEU in the Academic Year of 2010-2011}

In this section, we select the latest year of PPTEU, which is the academic year of 2010-2011, we observe the data via a micro perspective to examine this policy's actual practice and effect. Table 6 showed the profiles and statistics of HEIs awarded by this policy in the academic year of 2010 to 2011.

Table 6. Profile and Statistics of Selected HEIs in the Academic Year of 2010-2011

\begin{tabular}{lllll}
\hline Institutional Name & $\begin{array}{l}\text { Full-Time } \\
\text { College } \\
\text { Number }\end{array}$ & $\begin{array}{l}\text { Student } \\
\text { Full-Time Faculty }\end{array}$ & $\begin{array}{l}\text { Student/Faculty } \\
\text { Ratio }\end{array}$ & $\begin{array}{l}\text { Funding (Unit: 10 } \\
\text { thousand) }\end{array}$ \\
\hline Chinese Medical University & 6539 & 501 & 13.05 & 12000 \\
Yuanchi University & 7003 & 340 & 20.6 & 10000 \\
Feng Jia University & 16329 & 641 & 25.47 & 9500 \\
Soochow University & 11752 & 446 & 26.35 & 8500 \\
Tunghai University & 13598 & 544 & 25 & 7500 \\
Min-Chuan University & 16806 & 615 & 27.33 & 7000 \\
National Taipei University of Art & 1337 & 184 & 7.27 & 6599 \\
Taipei Medical University & 4482 & 435 & 10.3 & 6500 \\
Fu Jen University & 17755 & 713 & 24.9 & 6212 \\
Kaohsiung Medical University & 5730 & 522 & 10.98 & 4668 \\
Asia University & 9167 & 340 & 26.96 & 4668 \\
National Taiwan University of & 5233 & 419 & 12.49 & 4532 \\
Ocean & & 824 & 25.48 & 4510 \\
Tamkang University & 20996 & 314 & 30.23 & 4488 \\
Shih Hsin University & 9493 & 379 & 29.06 & 3903 \\
Providence University & 11015 & 389 & 12.07 & 3861 \\
National Changhua University of & 4697 & 388 & 7.03 & 3793 \\
Education & 2729 & 557 & 11.92 & 3773 \\
Tzu Chi University & 6640 & 141 & 21.29 & 3761 \\
National Chung Cheng University & 3002 & & & \\
Hua Fan University & & & & \\
\hline & & & & \\
\hline
\end{tabular}




\begin{tabular}{lllll}
\hline National Dong Hua University & 6890 & 480 & 14.35 & 3761 \\
Chung Yuan Christian University & 12579 & 503 & 25.01 & 3760 \\
National Taipei University & 5509 & 360 & 15.3 & 3500 \\
National Kaohsiung Normal & 3390 & 310 & 10.94 & 3380 \\
University & 2090 & 143 & 14.62 & 3000 \\
Fo Guang University & 7240 & 311 & 23.28 & 3293 \\
Da Yeh University & 11734 & 523 & 22.44 & 3272 \\
I-Shou University & 2275 & 165 & 13.79 & 3125 \\
National Taiwan University of & 20428 & 716 & 28.53 & 3083 \\
Arts & 4093 & 239 & 17.13 & 3042 \\
Chinese Culture University & 7777 & 528 & 14.73 & 3000 \\
National Ilan University & 6309 & 295 & 21.39 & 2218 \\
National Chia-Yi University & & & & \\
National United University & & & & \\
\hline
\end{tabular}

Source: Ministry of Education in Taiwan (2012b)

Table 7 is the data that we compare the average funding by full-time college student number categories. This table's data is those HEIs awarded by PPTEU in the academic year of 2010 to 2011, small-size HEIs received less average funding, whereas middle-size HEIs and large size HEIs receive relatively more funding. The difference is not large.

Table 7. College Student Number Category and Average Funding Awarded

\begin{tabular}{llll}
\hline $\begin{array}{l}\text { Full-time college students } \\
\text { number categories }\end{array}$ & Number of HEIs & $\begin{array}{l}\text { Average Funding } \\
\text { Awarded (Unit: Ten } \\
\text { Thousands) }\end{array}$ & Standard Deviation \\
\hline Small-Size HEI: Less than 5509 & 11 & 4099.36 & 1289.04 \\
Middle-Size HEI: 5510-9493 & 10 & 5186.90 & 3194.22 \\
Large Size HEI: 9494-20996 & 10 & 5724.00 & 2324.25 \\
\hline
\end{tabular}

Table 8 is also an analysis of average funding received by HEIs awarded by PPTEU, this time we divide the HEIs by their full-time faculty number categories. We found similar trend, the more faculty a university hire, the more average funding the university will receive.

Table 8. Faculty Number Category and Average Funding Awarded

\begin{tabular}{llll}
\hline $\begin{array}{l}\text { Full-time faculty number } \\
\text { categories }\end{array}$ & Number of HEIs & $\begin{array}{l}\text { Average Funding } \\
\text { Awarded (Unit: Ten } \\
\text { Thousands) }\end{array}$ & Standard Deviation \\
\hline Small-Size HEI: Less than 340 & 11 & 4324.90 & 2215.36 \\
Middle-Size HEI: $341-503$ & 10 & 5411.00 & 2814.84 \\
Large Size HEI: $504-824$ & 10 & 5251.80 & 2207.35 \\
\hline
\end{tabular}

Table 9 is another analysis of average funding received by HEIs awarded by PPTEU, this time we divide the HEIs by their student/faculty ratio. The number of student/faculty ratio means how many students shared by one faculty in that university. This time the finding is different with the above two tables. When universities have a middle range student/faculty ratio (14.36 to 24.90$)$, these universities receive relatively lower average funding 
than other universities.

Table 9. Student/Faculty Ratio and Average Funding Awarded

\begin{tabular}{llll}
\hline Student/Faculty Ratio & Number of HEIs & $\begin{array}{l}\text { Average Funding } \\
\text { Awarded (Unit: Ten } \\
\text { Thousands) }\end{array}$ & Standard Deviation \\
\hline Lower than 14.35 & 11 & 5090.18 & 2568.68 \\
$14.36-24.90$ & 10 & 4129.80 & 2313.11 \\
$24.91-30.23$ & 10 & 5691.20 & 2236.08 \\
\hline
\end{tabular}

\section{Conclusion and Implications}

This study reviews related literature of teaching excellence in universities and college student learning theories. The macro theories of sociology of education, including EMI and MMI, are also added into the discussion of this study. The study found out that the discourse of policy of teaching excellence in Taiwan is based on competitive mechanism. We found out that there are not any technical HEIs awarded in this program and most of the HEIs awarded in this program are comprehensive universities. Specialized HEIs, such as normal universities, and teachers colleges, and universities of physical education, and universities of arts become fewer when this policy runs into its fourth and fifth years. In terms of the relationship between universities' size and funding, we found there is a positive relation between size and funding. In terms of the relationship between full-time faculty number and average funding awarded, it shows that faculty number has an impact on HEI's average funding. But, when we consider the student/faculty ratio, it turns out that the higher 19 ratio HEIs, which means one faculty would share 24.91-30.23 students, then this kind of HEI will receive more funding. But the middle group, one faculty shares 14.36-24.90 students, receives the least average funding.

To sum up, the policy of promoting teaching excellence in Taiwan is based on a competition mechanism and it is considered as an efficient and equitable way to distribute funding to different types of HEIs in Taiwan. But, if we observe this policy via equality of educational opportunities and the aim of balancing universities' quality, this policy is questionable because of its neglect of technical HEIs and specialized HEIs. Also, to fund higher or lower student/faculty ratio institutions can also be discussed in the higher education policy making process.

The implications for future research are three folds. First of all, future study can interview faculty and ask them how they experienced the effects of this policy. Second, quantitative method, such as nation-wide survey can be done to understand the effects of this policy on different types and sizes of HEIs. Third, similar policies to promote teaching excellence in different countries in the world can be compared in the future study.

\section{References}

Arum, R., Gamoran, A., \& Shavit, Y. (2007). More Inclusion than Diversion: Expansion, Differentiation, and Market Structure in Higher Education. In Y. Shavit, R. Arum, \& A. Gamoran (Eds.), Stratification in Higher Education: A Comparative Study (pp. 1-35). Stanford, CA: Stanford University Press.

Astin, A. W. (1973). The Impact of Dormitory Living on Students. Educational Record, 54, 204-210.

Astin, A. W. (1975). Preventing Students from Dropping Out. San Francisco: Jossey-Bass.

Astin, A. W. (1977). Four Critical Years. San Francisco: Jossey-Bass.

Astin, A. W. (1999). Student Involvement: A Developmental Theory for Higher Education. Journal of College Student Development, 40(5), 518-529.

Astin, A. W. (2002). Assessment for Excellence: The Philosophy and Practice of Assessment and Evaluation in Higher Education. Westport: ORYX Press.

Ayalon, H., \& Shavit, Y. (2004). Educational Reforms and Inequalities in Israel: The MMI Hypothesis Revisited. Sociology of Education, 77, 103-120. http://dx.doi.org/10.1177/003804070407700201

Bourdieu, P., \& Passeron, J. C. (1990). Reproduction in Education, Society, and Culture. London: Sage Publications.

Bowles, S., \& Gintis, H. (1976). Schooling in Capital America: Educational Reform and Contradiction of Economic Life. New York: Basic Books. 
Cambridge, B. L. (2000). The scholarship of teaching and learning: A national initiative. In M. Kaplan \& D. Lieberman (Eds.), To improve the academy, 18, (pp.55-68). Bolton, MA: Anker.

Hannan, A., \& Silver, H. (2000). Innovating in higher education: Teaching, learning, and institutional cultures. Buckingham: Open University Press.

Hout, M., \& DiPrete, T. A. (2006). What We Have Learned: RC28's Contributions to Knowledge about Social Stratification. Research in Social Stratification and Mobility, 24(1), 1-20. http://dx.doi.org/10.1016/j.rssm.2005.10.001

Kreber, C. (2002). Teaching excellence, teaching expertise, and the scholarship of teaching. Innovative Higher Education, 27(1), 5-23. http://dx.doi.org/10.1023/A:1020464222360

Lin, Y. F., \& Chan, S. J. (2004). On the Differentiation Framework of the Post-Compulsory Education in Taiwan: A Perspective based on the Reflection on the Two-Educational Highway Policy. Educational Research \& Information, 12(6), 59-84.

Lucas, S. R. (2001). Effectively Maintained Inequality: Educational Transitions, Track Mobility, and Social Background Effects. American Journal of Sociology, 106(6), 1642-1690. http://dx.doi.org/10.1086/321300

McDonough, P. M. (1997). Choosing Colleges: How Social Class and Schools Structure Opportunity. Albany: State University of New York Press.

Ministry of Education in Taiwan. (1999). The Review of Vocational and Technical Education.

Ministry of Education in Taiwan. (2008). 2008 Edition Education Statistics: The Republic of China. Taipei, Taiwan: Ministry of Education.

Ministry of Education in Taiwan. (2012a). About this policy: Program for promoting teaching excellence of universities. Retrieved Feb. 14, 2012 from: http://www.csal.fcu.edu.tw/edu/program_start.asp

Ministry of Education in Taiwan. (2012b). Awarded HEIs and related statistics: Program for promoting teaching excellence of universities. Retrieved Feb. 14, 2012 from: http://www.csal.fcu.edu.tw/edu/program_school_les.asp

Mok, K. H. (2003). Globalisation and Higher Education Restructuring in Hong Kong, Taiwan, and Mainland China. Higher Education Research \& Development, 22(2), 117-129. http://dx.doi.org/10.1080/0729436032000083580

Paulsen, M. B. (2001). The Economics of Human Capital and Investment in Higher Education. In M. B. Paulsen, \& J. C. Smart (Eds.), The Finance of Higher Education: Theory, Research, Policy, and Practice (pp. 55-94). New York: Agathon Press.

Raftery, A. E., \& Hout, M. (1993). Maximally Maintained Inequality: Expansion, Reform, and Opportunity in Irish Education, 1921-75. Sociology of Education, 66(1), 41-62.

Robins, L., Ambrozy, D., \& Pinsky, L. E. (2006). Promoting academic excellence through leadership development at the University of Washington: The teaching scholars program. Academic Medicine, 81(11), 979-983.

Shavit, Y., Ayalon, H., Chachashvili-Bolotin, S., \& Menahem, G. (2007). Isreal: Diversification, Expansion, and Inequality in Higher Education. In Y. Shavit, R. Arum, \& A. Gamoran (Eds.), Stratification in Higher Education: A Comparative Study (pp. 39-62). Stanford, CA: Stanford University Press.

Skelton, A. (2004). Understanding "teaching excellence" in higher education: A critical evaluation of the National Teaching Fellowships Scheme. Studies in Higher Education, 29(4), 451-468. http://dx.doi.org/10.1080/0307507042000236362

Tsai, S. L., \& Shavit, Y. (2007). Taiwan: Higher Education-Expansion and Equality of Educational Opportunity. In Y. Shavit, R. Arum, \& A. Gamoran (Eds.). Stratification in Higher Education: A Comparative Study (pp. 140-164). Stanford, CA: Stanford University Press.

Yang, C. C. (2010). College access, equity, and student success in the context of higher education expansion and differentiation in Taiwan. Unpublished Doctoral Dissertation, University of California, Los Angeles.

\section{Note}

Note 1. The saturation of enrollment in MMI theory, defined by Tsai and Shavit (2007), refers to a hypothesis that some social origins' education transition rates approach $100 \%$. 